\title{
AMOBILISASI KOMPLEK KOBAL(II) PADA POLI(4-VINILPIRIDIN) DAN KARAKTERISASINYA
}

\author{
Syukri, Safni, Anna Fadhilla \\ Jurusan Kimia FMIPA Unand \\ email: syukri.darajat@yahoo.com
}

\begin{abstract}
Acetonitrile ligated cobalt(II) complex was successfully immobilized on poly(4-vinylpyridine) (P4VP). The grafted material was characterized by Fourier Transform Infra Red (FTIR), Scanning Electron Microscope (SEM), UV-Visible Spectrometry, Thermal Gravimetry-Differential Thermal Analysis (TG-DTA) and Atomic Absorption Spectrophotometry (AAS). The FTIR measurement confirmed a successful grafting indicated by the presence of a weak donor-acceptor interaction between $\mathrm{N}$ of poly(4-vinylpyridine) with the $\mathrm{Co}^{2+}$ of the complex. A change of surface morphology after immobilization process was evidenced by SEM photographs. TG-DTA analysis showed that the attached Co(II) complex on P4VP was found to be moderately thermally stable. The metal leaching of the obtained heterogeneous catalyst measured by AAS was found to be less than $0.1 \%$.
\end{abstract}

Keywords: Immobilization, Grafting, Heterogeneous catalyst, Donor-acceptor interaction, Surface area, Metal leaching

\section{DAFTAR PUSTAKA}

1. C. E. Housecroft and A. G Sharpe, Inorganic Chemistry, $2^{\text {nd }}$ Edition, Prentice Hall, 2005, 786-787.

2. T. Saito dan Ismunandar, Buku Teks Kimia Anorganik Online, Iwanami Shoten, Tokyo, 1996, 171-172.

3. A. Sakthivel, Syukri, A. K. Hijazi and F. E. Kühn, Heterogenization of $[\mathrm{Cu}(\mathrm{NCCH} 3) 4][\mathrm{BF} 4] 2$ on Mesoporous AlMCM-41/48 and its application as Cyclopropanation Catalyst, Catal. Letters, 3:(1-2), 43-49, (2006).

4. Syukri, A. Sakthivel, W. Sun, F. E. Kühn, Immobilization of $\mathrm{Ru}(\mathrm{II})($ salen $)\left(\mathrm{PPh}_{3}\right)_{2}$ on Mesoporous MCM-41/SBA-15 : Characterization and Catalytic Applications Syukri, Catal. Lett. 128, 18 -24, (2009).

5. Syukri, C. E. Fischer, A. Al-Hmaideen, Y. Li, Y. Zheng, and F. E. Kühn, Modified MCM-41-supported acetonitrile ligated copper(II) and its catalytic activity in cyclopropanation of olefins, Microporous and Mesoporous Materials, 113:(1-3), 171177, (2008).

6. Syukri, W. Sun, and F. E. Kühn, Immobilization of Ruthenium(II) Salen Complexes on Poly(4-vynilpiridine) and Their Application in Catalytic Aldehyde Olefination, Tetrahedron Letters, 48, 16131617, (2006).

7. Syukri, A. K. Hijazi, A. Sakthivel and F. E. Kühn, Heterogenzation of Solvent Ligated Copper(II) Complexes on Poly(4vynilpiridine) for the Catalytic Cyclopropanation of Olefins, Inorganica Chimica Acta, 360, 197 - 202, (2006).

8. A. K. Hijazi, A. Hmaideen, Syukri, N. Radhakrishnan, E. Herdtweck, B. Voit, and F. E. Kuehn, Synthesis and Characterization of Acetonitrile-Ligated Transition-Metal Complexes with Tetrakis(pentafluorophenyl)borate as Counteranions, Eur. J. Inorg. Chem., 2895, (2008).

9. B. Stuart, Infrared Spectroscopy: Fundamentals and Applications, John Willey and Sons, 2004, 82-82. 
